\title{
Working Families with Young Children and No Out-of-Pocket Child Care Struggle Financially
}

\author{
Marybeth J. Mattingly, Robert Paul Hartley, and Christopher Wimer
}

Working families with young children face substantial barriers in accessing and affording quality child care. Figure 1 shows that among working families with a child under age 3, those who do not pay for child care are more likely to live in poor or low-income families than those who do pay for child care (61 percent versus 45 percent). These income differences suggest that cost may be an obstacle to greater labor force attachment or desired care arrangements among those who currently do not pay for care. Given the burden of high child care costs, along with the recent national attention paid to child care, it is worth thinking about policies that would help make child care more affordable. For example, simply making the Child and Dependent Care Tax Credit refundable could lower barriers to work for poor families with young children, and expanding this credit could improve access to paid child care.

\section{FIGURE 1. DISTRIBUTION OF WORKING FAMILIES WITH CHILDREN UNDER AGE 3, BY POVERTY STATUS}

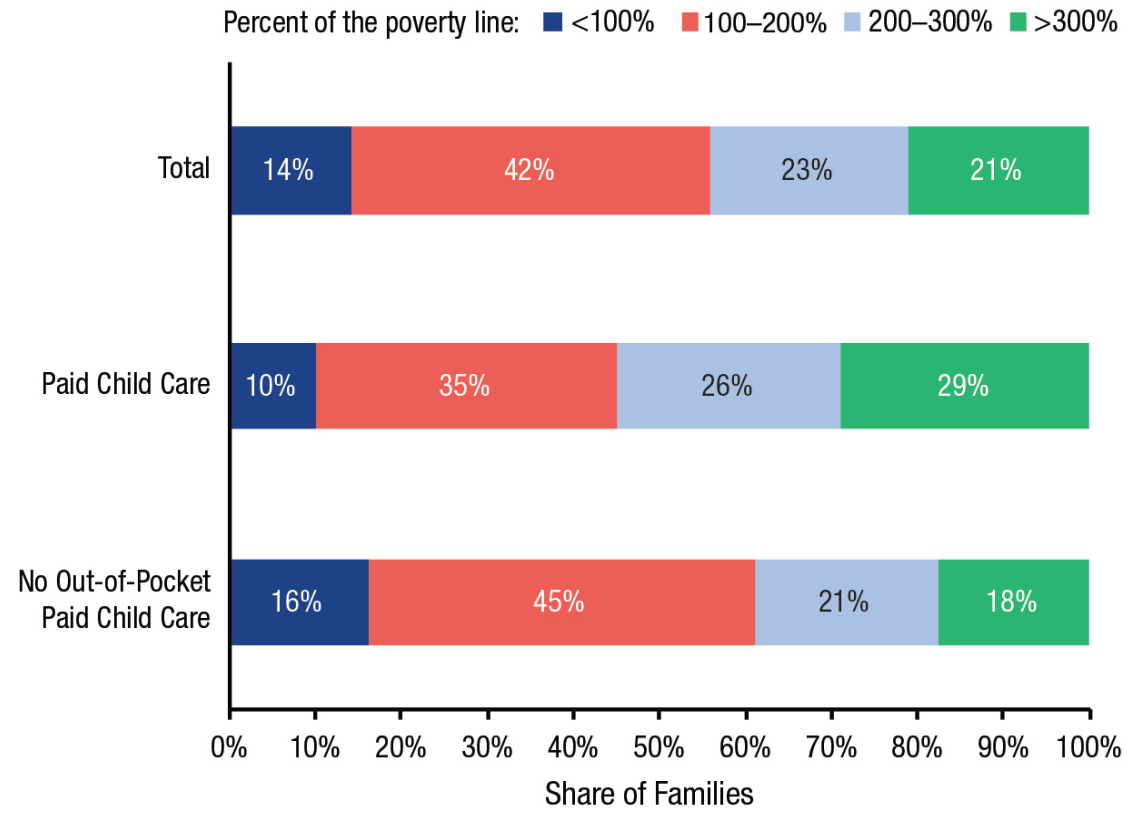

Source: 2012-2016 Current Population Survey, Annual Social and Economic Supplement. Poverty status is defined using the U.S. Census and Bureau of Labor Statistics estimates of the Supplemental Poverty Measure.
Families that report no out-of-pocket child care expenses work about $27 \%$ [or 8 ] less hours per week than those paying for child care.

\section{See related publications}

- Poorer Working Families With Young Children Are Unlikely to Afford Child Care (December 2017)

- Child Care Costs and Poverty Among Families With Young Children (October 2017)

- Child Care Expenses Push Many Families Into Poverty (May 2017)

- Child Care Costs Exceed 10 Percent of Family Income for One in Four Families (November 2016)

This research was made possible by a gift from Jay Robert Pritzker and Mary Kathryn Pritzker. 